\title{
4 \\ China's Impact on New Zealand Foreign Policy in the Pacific: The Pacific Reset
}

lati lati

\section{Introduction}

This chapter examines New Zealand's 'Pacific Reset' (Reset) policy to determine whether it is a response to anxieties about China's growing presence in the Pacific Islands region. In March 2018, New Zealand's Minister of Foreign Affairs and Trade Winston Peters announced the Reset and its significant policy shift, both financially and diplomatically. The Reset includes a NZ\$714.2 million allocation to New Zealand's Official Development Assistance fund, with the Pacific as the major recipient, and 14 new diplomatic posts. On its face, this is a significant change in New Zealand's foreign policy in the Pacific. Intriguingly, Peters' announcement was made the day after former United States secretary of state Hillary Clinton, in a visit to New Zealand, warned of China's soft power push into the Pacific. It also came amidst concerns expressed by New Zealand and Australian officials about China's chequebook diplomacy in the region. Despite this seemingly obvious reason for the Reset, the New Zealand Government insists it was not prompted by China's activities in the region. 
This chapter argues that the Reset is intended to address concerns about China's increasing presence in the Pacific and is a result of the perspective New Zealand has adopted about China's place in the region. This perspective has largely been influenced by years of neglect of the region by Western powers, a point that has often been stressed in New Zealand foreign policy circles, but usually by those not directly involved in the decision-making processes. These years of neglect were accompanied by the use of aid as a political tool, often as leverage over Pacific Island countries, a point not lost on foreign policy observers, particularly those in the region. New Zealand's perspective has also been influenced by the rise in the number of external actors in the region, giving the impression of a more contested Pacific geopolitics. While these external actors pose no real rivalry to the incumbents, they raise interesting possibilities, which are influencing how New Zealand views the region. For a country that has since World War II taken strong measures to provide a security architecture in the region, both for itself and its allies, these possibilities can appear threatening.

Whether New Zealand's perspective about China is accurate is another matter. Though New Zealand has always welcomed Chinese money, it has been more ambivalent about its political presence in the Pacific. On this front, New Zealand has clearly taken the position that China's activities, as it perceives them in the context of regional geopolitics, are troubling and warrant a response of the magnitude of the Reset. This chapter examines various statements and arguments contained in speeches about the Reset, the policy context in which the Reset was formulated and the most recent document produced by the New Zealand Ministry of Defence, which complements the Reset. These strongly suggest China is the focus of the Reset.

\section{What is behind the Pacific Reset?}

The Reset was announced in March 2018 by New Zealand's Deputy Prime Minister, the Honourable Winston Peters, at a speech delivered at the Lowy Institute (Peters 2018a). According to Peters, there were several reasons for the Reset. First, the Reset is part of a 'dramatic' change in both the domestic and foreign policies of the coalition government, which came into power in late 2017. The coalition is made up of three political parties: the Labour Party (one of the two major parties), New Zealand 
First and the Greens. Notably, both the Minister of Foreign Affairs and Trade and the Minister of Defence are from New Zealand First, a party that sits on the centre-right of New Zealand politics. Second, the Pacific is facing 'social and environmental problems', which are 'attracting an increasing number of external actors and interests'. According to Peters, these problems are prompting changes that, at times, are not ideal for the Pacific Island countries, because the 'need and temptation often leads to greater risk than prudence would suggest'. In response, New Zealand wants to be a good neighbour and assist Pacific Island countries in addressing these challenges in a way that preserves their autonomy. Third, the Pacific is becoming more important to international relations. Fourth, stability in the Pacific is critical to New Zealand's national security. Peters noted that these reasons needed to be understood, in particular the following geographical, historical and social facts about New Zealand: it is a Pacific country, historically, culturally, politically and demographically, and 'the Pacific is where New Zealand matters more, wields more influence and can have a more positive impact'. In other words, New Zealand is a small player in international relations, but in the Pacific region, constituted primarily by microstates, it has and wields considerable influence. While it is not a 'big power', it can act like one.

Is the Reset aimed at countering the influence of China in the Pacific? The New Zealand Government has not directly said that this is the Reset's purpose; in fact, Peters has stringently denied that the Reset is 'specifically to counter China' and instead explained in a 2018 Radio New Zealand interview that it is designed:

to ensure that the shape and character of our neighbourhood maintains the level of influence of countries who believe in democracy ... who believe in sovereignty and countries who have got the best interest of the neighbourhood in mind, not some wider and larger purpose (Radio New Zealand 2018f).

Although a number of commentators have inferred a link between the Reset and increasing Chinese influence (Novak 2018; Reuters 2018; Walters 2018b), they provide no direct evidence.

However, there is considerable circumstantial evidence that the purpose of the Reset is to counter China. A report by Stanford University's Hoover Institution, Chinese Influence and American Interests: Promoting Constructive Vigilance, argues that New Zealand is 'vulnerable to Chinese influence' and that 'China appears ready to exploit' New Zealand's 
pursuance of closer ties with it 'to subvert New Zealand's continued ability to independently shape its policy priorities' (Diamond and Schell 2018:169). In the aforementioned radio interview (Radio New Zealand 2018f), Peters was asked to respond to the following comment:

It [the report] goes on to say that New Zealand has long pursued ties with China but what is changing is the willfulness with which China appears to exploit the dynamic with New Zealand and to subvert New Zealand's continued ability to independently shape its policy priorities. What are you doing as foreign minister to counter that?

Peters replied:

You know what I'm doing to counter that. The first thing we did when we became a government and I became foreign minister was set out to evaluate what had gone on and that's why we've got the Pacific Reset, which is a huge turnaround in our approach to our neighbourhood and our engagement with it, and our engagement in it, and our engagement with each ... every government in the Pacific and also those other players such as Japan, Australia, the European Union, the UK, France (ibid.).

At the very least, Peters' conflicting statements suggest that China is a factor in the Reset.

A critical analysis of Peters' Lowy Institute speech and subsequent rhetoric and actions sheds further light on this issue. Specifically, Peters stated that the Pacific:

has also become an increasingly contested strategic space, no longer neglected by great power ambition, and so Pacific Island leaders have more options. This is creating a degree of strategic anxiety (Peters 2018a).

Arguably, China is the great power New Zealand is strategically anxious about. China, the US and perhaps France are the only great powers active in the region, and, of these, China is the relative newcomer. France and the US have long histories as colonisers in the Pacific and continue to control their dependencies and, in the case of the US, Compact of Free Association states. As such, it is nonsensical to believe that France and the US are the ones Peters referred to as having 'great power ambition' in the Pacific, even taking into consideration the recent inclusion of the French dependencies in the Pacific Island Forum (PIF). Further, it would be 
surprising if New Zealand was becoming strategically anxious about the actions of the US in the region after both countries signed the Wellington and Washington declarations in 2010 and 2012, respectively. Both declarations, but especially the first, commit each country to enhancing their partnership in the Pacific, particularly in addressing security issues. Of the great powers in the Pacific (the UK effectively departed after the Cold War and is only now reestablishing ties), China is the only one whose ambitions would cause New Zealand strategic anxiety.

However, anxieties about the increasing presence of China in the Pacific must be understood in context. If New Zealand had retained its traditional influence in the Pacific, a response to China's increasing influence in the magnitude of the Reset might not have been required. Instead, it is the relative demise of New Zealand's, and its allies', influence that is causing consternation in Wellington and gave rise to the Reset. One area where this is particularly noticeable is in Pacific regionalism, or regional cooperation between Pacific countries, including former colonial powers. New Zealand's and Australia's domination of Pacific regionalism is no secret. Initially, regionalism served the interests of the metropolitan powers, and it was not until the 1960s that 'Island leaders began to challenge this biased regional framework' (Tarte 1989:183). Even then, because these powers provided the bulk of the funding to the main regional organisations-the Pacific Community and the PIF (New Zealand and Australia for the PIF)- they were best positioned to control the regional agenda in pursuit of their interests (Bryant-Tokalau and Frazer 2006:2). Nevertheless, the Western powers', particularly Australia's and New Zealand's, domination of Pacific regionalism is waning. Led primarily by Fiji, Pacific Island countries are gaining greater control over the regional agenda, not only with the formation of new organisations such as the Pacific Islands Development Forum, but also in determining the agenda of the premier regional organisation, the PIF (Fry and Tarte 2015).

\section{Does the Reset entail a new direction in New Zealand foreign policy?}

The policies that constitute the Reset lift New Zealand-Pacific relations to a different level, and appear to push them in a different direction. According to Peters, the Reset has two distinct strands: 'back-to-basics' diplomacy and an increase in assistance. The first involves engaging Pacific 
countries with New Zealand's views of the 'strategic environment facing the Pacific, including the proliferation of external actors' (Peters 2018a). This follows five principles approved by the New Zealand cabinet:

1. Demonstrate understanding of the Pacific shaped by government and non-government actors.

2. Exhibit friendship through more interaction, in particular frank conversations at the political level, which also entails a greater focus on the Pacific than previously.

3. Strive for solutions of mutual benefit.

4. Achieve a collective ambition, whereby New Zealand and its allies would work together with Pacific countries and other external actors to achieve common aims.

5. Seek sustainability.

The second involves a budgetary increase, which had not been done since 2008, and a rise in New Zealand diplomatic expertise, particularly in the Pacific. According to Peters, this will demonstrate New Zealand's commitment to the region, allowing New Zealand to do more in relation to issues such as climate change, good governance, human rights and women's political development, as well as give more funding to multilateral institutions. Overall, New Zealand seeks 'leadership diplomacy', in conjunction with Australia, that goes beyond the 'donor/ recipient interaction and into genuine, mature political partnerships' that involve 'understanding, friendship, mutual benefit, and collective ambition, to achieve sustainable results' (ibid.).

The two most important changes in the Reset are the level of investment in the diplomatic core that engages on Pacific issues and the change from a donor-recipient model to one of partnership. As noted, one of the glaring deficiencies or issues with New Zealand's previous Pacific engagement was its relative lack of attention to diplomatic integrity; while professionals designated to regions such as Asia and Europe were equipped with relevant language and cultural training, the same was not expected of those sent to the Pacific. This is not to say that those deployed to the Pacific were not well versed in Pacific languages or cultures, or were not genuinely focused on the region. However, according to Powles and Powles (2017), New Zealand diplomats to other regions are expected to have greater expertise than those sent to the Pacific. In most other regions, it is usual practice to appoint 'senior New Zealand diplomats 
with training and professional experience in the field of diplomacy (Powles and Powles 2017:20). In many cases, these diplomats will have been trained in local languages by the Ministry of Foreign Affairs and Trade. By comparison, New Zealand has a much lower proportion of professional diplomats heading its Pacific posts (ibid.). Peters implicitly hints at this phenomenon, stating that the Reset is a 'strategy based on mutual respect' (Peters 2018a). If the Reset entails a radical change, was there a lack of mutual respect previously?

New Zealand's Pacific identity came to the fore of its foreign policy in the early 1970s, particularly with the Kirk Government. However, whether New Zealand was seeking a partnership with the region, or regarded their relationship as something less, is questionable. Gerald Hensley, a New Zealand diplomat and head of the prime minister's department under two administrations, notes that during the early years of the Pacific-focused foreign policy approach, New Zealand demonstrated a lack of genuine and meaningful engagement:

The new emphasis on the South Pacific, however, was no more than a polite fiction ... Revealingly, politicians and diplomats who carried the message of NZ's Pacific identity to foreign governments rarely confirmed their words by wanting a posting there (Hensley 2013:307-8).

The Pacific was a convenient (or inconvenient) means to an end: 'The stress on the South Pacific was a fig leaf to cover a more fundamental withdrawal from the world' (ibid.).

Rightly or wrongly, New Zealand has also used its aid to the Pacific as a tool to control, or at least influence, the region to advance its own interests. For the past several decades, New Zealand has dedicated the majority, approximately 60 per cent, of its overseas development assistance to the Pacific, but not for altruistic reasons. John Henderson, who served as the head of the prime minister's office under David Lange, noted:

A 1989 audit report of MERT [Ministry of External Relations and Trade] identified foreign aid as a 'principal tool in our foreign policy' in the South Pacific. It noted the importance of aid for providing access to key decision makers at both the political and official levels. While the report also emphasised the role of aid in developing island state economies, it linked this to reducing the scope for outside 'undesirable influences' to meddle in the region. ... Political outcomes were more important than the economic 
and humanitarian reasons for providing the aid. Aid was an important instrument of foreign policy. As the 1990 policy review put it: 'Our mana as a people of the Pacific is maintained through our ODA because it gives substance to our relationships' (1999:287-88).

Pacific leaders and other commentators on Pacific geopolitics have long known the inequity of this relationship, as well as New Zealand's, and its closest ally Australia's, condescending and overbearing approach. The PIF (formerly the South Pacific Forum) was specifically formed to give Pacific countries more autonomy from the regional influence of metropolitan powers, including New Zealand. New Zealand, along with Australia, was associated with the colonial approach to regionalism and, understandably, was not initially included as a full member of the PIF; they were observers (Tarte 1989:184). Regional leaders such as Fiji's first prime minister Ratu Sir Kamisese Mara expressed concerns about New Zealand's and Australia's dominance of the regional agenda (Bryant-Tokalau and Frazer 2006:3). These concerns were later echoed by other leaders and commentators. Bryant-Tokalau and Frazer noted:

For inter-governmental organisations in particular, the funding and involvement of Australia and New Zealand has meant a striking asymmetry of power in the running of those organisations and in the settling of regional policy (ibid.).

They conclude that while it would be going too far to say that Pacific countries 'have completely lost control of the regional agenda ... it is not very clear just how much control they have left' (Bryant-Tokalau and Frazer 2006:20). Winston Peters' rhetoric suggests that New Zealand is finally acknowledging the asymmetrical power relationship between it and Australia on the one hand, and the Pacific Islands on the other, and is prepared to treat the Pacific Island countries as equals and partners.

New Zealand's back-to-basics diplomacy, which kicked off with a tour of the region in 2018 and a plan to 'spend considerable time' there (Peters 2018a), suggests a new-found emphasis on relationship building. The five principles of the Reset indicate not only the policy areas of future focus, but also past neglect. Notably, there is an emphasis on engaging the Pacific as equals, something that was obviously lacking previously. Peters' rhetoric is telling. He noted that exhibiting friendship includes 'honesty, empathy, trust and respect', which 'means staying in frequent touch at a political level' (ibid.). He also noted, in reference to Australia, that 'I suspect our 
two countries ... have been preoccupied with other parts of the world when building on our own borders are matters of concern' (ibid.). His last statement speaks to Hensley's point.

New Zealand has neglected the Pacific, but Peters underestimates the extent to which and ways this has been done. He is correct that New Zealand has not devoted as much financial resources to its relationship with the region as other Pacific partners, such as Australia and China, and that, diplomatically, New Zealand has not paid enough attention to Pacific Island countries' perspectives. New Zealand has treated the region as a recipient, a tool in its broader foreign policy objectives. However, Peters fails to appreciate, or at least express, that New Zealand's and Australia's overbearing and neo-colonial approaches have resulted in a failure to recognise that these countries are not just sovereign, but autonomous. Not only do many have legal standing in the international community as sovereign nation-states, they also have been striving, as independent countries, to control their affairs without undue influence from abroad, particularly from their previous colonisers, of which China is not a part. Peters' Lowy Institute speech betrays a foreign policy attitude not dissimilar from the past. On the one hand, he stated that 'Pacific countries want to stand on their own two feet as equals, make their own choices and have their distinctive voices heard on the global stage', and the Reset 'will be a strategy based on mutual respect' (Peters 2018a). On the other, he stated:

New Zealand's view is that we must be respectful of Pacific Island countries' clear wish to manage their own international relations while at the same time retaining New Zealand's traditional emphasis on human rights, the rule of law, transparency, good governance and the promotion of democracy (ibid.).

And then, 'But make no mistake. Isolation and a lack of size is no excuse for failing to strive for the best of standards' (ibid.). This is somewhat reminiscent of the hermeneutic rule: forget the nonsense before the 'but'. Aid conditionality based on what New Zealand considers 'good governance' appears to be as firm a part of New Zealand's foreign policy approach as it has always been. 


\section{To what extent has the Pacific become a more contested geopolitical space?}

More external actors are seeking diplomatic relations with Pacific Island countries. Aside from the usual suspects, such as the US, China, Taiwan and Japan, a number of other external governments are entering or reentering the Pacific geopolitical scene. Britain, whose presence in the region waned in the 1990s, is officially back. In early 2018, it announced a major reengagement with the Pacific, involving, among other things, the reopening of embassies in Tonga, Samoa and Vanuatu. This could be an inconsequential development. According to Fraenkel, 'I don't really see the connections with the Island states figuring in a major way in British foreign policy in the future. It's too far away and its interests aren't there' (Radio New Zealand 2018a). However, the fact that Britain reopened only nine diplomatic posts around the world, and three are in the Pacific, suggests something more significant.

Among the new or newer actors are Indonesia, India, Russia and, most recently, Israel. Although their contributions and influence in the region pale in comparison with established Pacific hegemons, their presence makes the geopolitical scene interesting, if for no other reason than that they are giving Pacific Island countries more options for assistance, however little it might be relative to that provided by the traditional benefactors. Nevertheless, there may be other reasons to take these actors seriously.

Russia, though far from being a player in the Pacific, is appearing on the region's geopolitical radar. Russia has been actively seeking to build ties with countries in the Asia-Pacific region, including Fiji (Muraviev 2018). In 2012, Russian Minister of Foreign Affairs Sergey Lavrov became the first senior Russian government official to visit Fiji. This was reciprocated a year later when Fijian Prime Minister Voreqe Bainimarama made an official state visit to Russia. In January 2016, Russia donated approximately 20 containers carrying weapons and military hardware to Fiji. Russian military personnel were then sent to train the Fijian military on their use. Fijian government officials said the weapons were to be used to rearm Fijian peacekeepers serving in United Nations missions (Doherty 2016). In 2017, Russia based 100 personnel in West Papua and flew two nuclear-capable Tu-95 bombers over the South Pacific in late 2017, taking off from airfields in Indonesia (Knaus 2017). In May 2018, a Russian training warship arrived in Papua New Guinea (PNG) 
and was welcomed by PNG officials. Interestingly, the visit was termed by PNG's minister for foreign affairs and trade Rimbink Pato as a 'pre-APEC gesture of friendship' (Riordan 2018), even though APEC was scheduled for November. Peters' concerns about the Pacific being a contested geopolitical space are well-founded.

\section{Is China's presence posing a threat to New Zealand?}

Since China entered the Pacific in 1975, signing diplomatic agreements with Fiji and Samoa, its presence and influence have risen dramatically, particularly in the post-Cold War era when powers like the US and Britain visibly withdrew. By the 2000s, it was not uncommon for Pacific Island countries to espouse 'Look North' policies (Crocombe 2007; Henderson and Reilly 2003). Though China's purpose was initially to counter Taiwan's efforts to gain diplomatic recognition as the official government of China, this has morphed into something larger, especially in past two decades.

China's increasing presence threatens the influence that the Western allies, particularly the US, have enjoyed in the Pacific for much of the 20 th century. Whether China is seeking to become the regional hegemon, and in particular challenge and perhaps supersede the US, is not known. On the one hand, it could be argued that China uses the Pacific to test its power against the US and its allies as part of its global aspirations for hegemony (Henderson and Reilly 2003). On the other hand, China's rise in the region could be seen as typical for a rising global power, and it possibly has no specific intention to challenge the US or any of its allies (Crocombe 2007). Regardless of the viewpoint taken, there is no doubt that New Zealand and its allies view China as a threat to their interests, especially if its growing influence is not made to conform to the rulesbased international order they largely created.

China's initial move into the Pacific was welcomed by New Zealand's allies, in particular the US, as a way to counterbalance Russia. New Zealand also welcomed China's engagement in the region, but probably more for the possible increased economic and trade opportunities. As a small and isolated country, New Zealand places a high value on trade. Since the 1970s, when Britain, then its largest export market, joined the EEC (European Economic Community, now the European Union), New Zealand has had to seek trade opportunities elsewhere, particularly Asia. As such, China has been a focal point for trade relations. This was 
exemplified when New Zealand became the first OECD (Organisation for Economic Co-operation and Development) country to sign a free trade agreement (FTA) with China. The FTA was enacted despite New Zealand having a reputation for being a moral foreign policy actor, and despite China's human rights record. For these reasons, New Zealand remains supportive of China's presence in the Pacific.

However, New Zealand is more ambivalent about China when it comes to security and strategic issues. In April 2018, media reports suggested that China had military ambitions in the Pacific. One report claimed that China had approached Vanuatu about a military buildup, though no formal proposals were made (Wroe 2018). Australia's 9News network 'confirmed' that the Australian Defence Force was aware that China had 'sounded out Vanuatu about increasing its military engagement' (Uhlmann 2018). In response, New Zealand Prime Minister Jacinta Ardern noted that she could not comment on the validity of the report, but that New Zealand is 'opposed to the militarisation of the Pacific' (Walters 2018a). Deputy Prime Minister and Foreign Affairs Minister Winston Peters stated the militarisation of the Pacific is 'something New Zealand had been "seriously concerned about" for a while now' (ibid.). Though he did not specifically mention China, Peters did note:

There were a number of players doing certain things in the Pacific that are not good for the peace and security, long-term, of the Pacific, or for the growth of democracy itself.

Apart from New Zealand's allies, China is the only other big player that can affect regional peace and security. Importantly, Peters' statements came one month after his announcement of the Reset, where he predicated the change on 'strategic anxiety' about the Pacific becoming 'an increasingly contested strategic space, no longer neglected by great power ambition' (Peters 2018a). Unless New Zealand was strategically anxious about the actions of the US, Australia or Japan, China is the only other option. New Zealand wants Chinese money, but fears Chinese political and military influence.

Since the Reset was announced, New Zealand has ramped up its Pacific engagement. It announced 14 new diplomatic posts as part of the Reset, 10 in the Pacific, including Hawai $i$, and four Tokyo, Beijing, Brussels and New York, 'to co-ordinate development policy and partnerships for the Pacific region' (Radio New Zealand 2018g). Notably, the New Zealand Ministry of Defence's Strategic Defence Policy Statement 2018 
(New Zealand Government 2018), released shortly afterwards, indicated a closer intertwinement of foreign affairs and defence priorities. A 2019 New Zealand Ministry of Defence publication, Advancing Pacific Partnerships, has a section entitled 'Defence's Pacific Reset', which makes it clear that Defence's strategic policy settings are aligned with the Reset (New Zealand Government 2019).

The Strategic Defence Policy Statement 2018 (Statement) sets out the principles that guide New Zealand's defence policies. China is, again, treated with ambivalence. On the one hand, New Zealand recognises China's importance to the region and world affairs, particularly in relation to what it perceives as the international rules-based order (IRBO). On the other, it explicitly and implicitly expresses concern about China's pursuit of its interests internationally, including in the Pacific. It notes that Washington and Beijing are in competition with each other, and that this has consequences for other countries. Importantly, it notes that China does not promote, or adopt, similar values to the order's 'traditional leaders', including around governance, human rights, development and economic liberalism. Further, it argues that, in some instances, particularly in military affairs, China is challenging the IRBO. It is within this context that China's increasing presence is discussed. Although the Statement does not specifically mention the Pacific, it states that the challenges posed to the rules and norms by countries that are in pursuit of 'spheres of influence', 'is a risk for open societies, including New Zealand'. China is one of the countries (Russia is the other) that is specifically identified as pursuing 'spheres of influence' (New Zealand Government 2018:17). China's influence internationally and in the Pacific is prompting new narratives about New Zealand defence.

Notably, the Statement also expresses concern about Russia. It notes that, in integrating into the IRBO, Russia, like China, has not always done so in accordance with the values and principles of the traditional leaders. Indeed, Russia has gone further. It "has attempted to discredit Western democracy by challenging its "internal coherence", leveraging information operations, and exploiting existing fissures with Western societies' (ibid.). Though Russia is not mentioned in relation to the Pacific, two factors connect it to the region. First, Russia is viewed as an ally of China. Second, Russia is making its presence felt in the Pacific. While China and Russia are not acting in concert in the region, at least not explicitly, the possibility that they may in the future cannot be ruled out. 
China's rising presence in the Pacific can easily be construed as a threat to New Zealand's interests in the region. First, it gives Pacific countries an alternative source of financial assistance, giving them more leverage when engaging with traditional benefactors, and arguably more autonomy. Whereas New Zealand's attaches conditions to its aid, China does not, although recipient countries are expected to adhere to its One China policy. Often, recipient countries have more discretion in how Chinese grants and soft loans are used as opposed to aid from New Zealand. In fact, China provides financial assistance for specific projects requested by Pacific Island countries, such as funding for new infrastructure, swimming pools, parliament buildings, wharfs and the like. The China alternative reduces New Zealand's ability to use aid as a political tool in the Pacific.

China's policies, and the way it engages Pacific Island countries, often do not support New Zealand policies, not that they should. For example, China does not promote good governance or human rights. New Zealand has and continues to promote these and similar norms; according to Peters, these are non-negotiable parts of the Reset (Peters 2018a). From a New Zealand perspective, China also follows an alternative model of development, which the Statement conceptualises as 'a liberalising economy absent liberal democracy' (New Zealand Government 2018:17). These threats to New Zealand's interests are not new, and analysts such as Henderson and Reilly (2003) have examined them. However, they appear relevant to the current government's view of China.

Newer concerns involving security matters are also emerging. The first is the possibility of a Chinese military presence in the Pacific Islands region. Aside from rumours, this concern also springs from a belief that Chinese economic policies are intertwined with their military ambitions. China's economic growth has been accompanied by an increase in its military power (Robertson and Sin 2017:91) and there is speculation from the US, at least, that the two go hand in hand. With reference to both Asia and the Pacific, former deputy assistant secretary of defence for South and Southeast Asia Joseph Felter claimed that China was aiming to establish 'dual-use' facilities, such as commercial ports, that could be converted to military bases (Radio New Zealand 2018c). This should not be a surprise; as China's economic power increases it will expect a role in the Asia-Pacific commensurate with its rise (Mapp 2014:2). 
The intertwinement of Chinese economic and military goals has been associated with the debt-trap narrative. China's economic plans, known popularly as the Belt and Road Initiative (BRI) include 'Pacific pathways' (Garrick 2018), and seven Pacific countries have signed up for it: PNG, Samoa, Fiji, Niue, Cook Islands, Tonga and Vanuatu (Radio New Zealand 2018e). According to Garrick (2018), the fear is that China will use the loans associated with its BRI as leverage to expand its military footprint.

The debt-trap narrative was most prominently deployed at the AsiaPacific Economic Cooperation meeting held in PNG in 2018 by US Vice President Mike Pence, who accused China of luring developing countries into debt traps through infrastructure loans. China, in return, rejected the accusation, highlighting the fact that no country in the world had fallen into a 'so-called debt trap because of its cooperation with China' (The Economic Times 2018). However, China's promised US $\$ 4$ billion of finance to build PNG's first national road network (Global Construction Review 2017) does prompt questions about PNG's debt situation and the implications of China's financing.

Pence was not the first to use the debt-trap narrative. In early 2018, US Pacific Fleet commander Admiral Scott Swift warned that China would increase debt in a given country and then ask for something in return that was not part of the original deal (Parker and Chefitz 2018). Parker and Chefitz argued that Pacific countries should be included in those that could be affected by China's debtbook diplomacy, particularly Tonga, Vanuatu and PNG. They noted that China is 'positioning itself to capitalise on the impending fiscal distress of Pacific Island countries' (Parker and Chefitz 2018:41). Since that 2018 report, the narrative has gained traction. Former Australian foreign minister Julie Bishop noted, 'We want to ensure that they [Pacific Island countries] retain their sovereignty, that they have sustainable economies and that they are not trapped into unsustainable debt outcomes', and that 'the trap can then be a debt-for-equity swap and they have lost their sovereignty' (Power 2018). Seidel (2018) argued, 'Debt-trap diplomacy is behind a new land grab'. Rightly or wrongly, New Zealand has been implicated as one country that is countering the possibility of debt traps through an extensive campaign of aid, trade and diplomacy (Lintner 2018; Kehoe 2018; Wu 2018).

Not all are convinced of the debt-trap argument. According to Fox and Dornan (2018), this argument is predicated on 'anecdotal evidence' rather than 'hard data'. Using international debt data, Fox and Dornan 
argued that, although debt is a problem in the Pacific Islands region, the 'debt distress' is not a result of lending by China. They note that 'Chinese lending comprises less than half of lending in any single country' and makes up around 12 per cent of the total debt owed by Pacific nations, even though China is the largest bilateral lender. Notably, 88 per cent of the total owed by Pacific nations is comprised of debts by PNG and Fiji. However, in both countries, 'domestic debt dominates government borrowing'. Further, 'it is only in Tonga, Samoa and Vanuatu that Chinese lending comprises over one-third of total debt', and the debt-trap only has basis in relation to Tonga, where there is a 'high level of debt distress, and Chinese lending dominates'. Fox and Dornan concluded that the debt-trap argument 'is without foundation'.

The potential problem of Pacific Island countries falling into significant debt is a concern to New Zealand. Deputy Prime Minister Peters cautioned Pacific governments about walking into debt traps (Walsh 2018), and Japan has expressed interest in cooperating with New Zealand to resolve the Pacific Island debt problem (Radio New Zealand 2018d). New Zealand has good reason to be concerned about the possibility of debt traps. The problem with Fox and Dornan's argument, and conclusion, is that it is predicated on the debt level of the region as a whole. Clearly, China does not need to have the entire region in a high-debt ratio to itself in order for the debt-trap narrative to have basis. The region does not act as a single entity, but as independent, sovereign countries. China only needs at least one country in the region to be in a debt-trap scenario in order for the narrative to make sense. It is akin to arguing that there was no debttrap problem in Asia before Sri Lanka gave up its port to Chinese control. Even if only Tonga and/or PNG and Fiji gives up control of its ports, or some other strategically important asset, the debt-trap narrative could make sense. Further, the level of debt does not have to be the key issue in this narrative. Instead, it is the extent to which debt would allow China to have undue influence on the recipient countries in question (O'Keefe 2018). China does not need to be the biggest creditor to these countries in order to achieve this. Nevertheless, it is one of the biggest creditors in some cases, like Vanuatu, where about half of the country's foreign debt is owed to China, and Tonga, where 60 per cent of the country's foreign debt is owed to China (Klan 2018). China does not need control of strategically important assets in every Pacific Island country. 
If debt issues can pave the way for increased Chinese military presence in the region, as aforementioned, this would be problematic for New Zealand's interests in the Pacific and threaten what has long been the Western allies' security control over the region. Before New Zealand took over some of the German colonies in the region on behalf of Britain at the beginning of World War I, it had long held aspirations to project military might in the Pacific. The opportunity to do so arose post-World War II. As the victorious great powers (US, Great Britain and China) planned the division of Japan's Pacific territories, New Zealand and Australia made their own play for strategic control of the region through the Canberra Pact (or the ANZAC Pact) (McIntyre 1995:227). The pact continues to inform New Zealand defence and security policy through the present (New Zealand Government 2018). It provides for a 'permanent machinery for collaboration and cooperation' between the two countries in all defence matters of mutual interest, to the extent that they are acquainted with each other's mindset, so that there will be 'the maximum degree of unity' in the presentation of their views 'elsewhere' (Vandenbosch and Vandenbosch 1967:21). The pact is important to the principle of New Zealand and Australia being a 'single strategic entity' (McKinnon 1998). The US, for its part, has had control over the Micronesian region's security issues, particularly through its compacts of free association with Palau, Marshall Islands and the Federated States of Micronesia, for the better part of the 20 th century to the present.

The Australia, New Zealand and United States Security Treaty (ANZUS Treaty) has played an important role in the collective security policies of those countries in the Pacific. Though the 1984 Lange Government's nuclear-free policies caused the cessation of the ANZUS Treaty commitments between New Zealand and the US, relations have largely been restored by the Wellington and Washington declarations. Notably, the Wellington Declaration commits the two countries to a strategic partnership in the Pacific. Further, these declarations were signed around the same time the US made a visible return to the region. In 2009, in response to the Australian 2009 Defence White Paper, then US secretary of state Hillary Clinton stated, 'We want Australia, as well as other nations, to know that the United States is not ceding the Pacific to anyone' (Davies 2009). She was referring to the broader Asia-Pacific region, but the Pacific was a key consideration. In 2011, the US built one of its largest embassies in Australasia in Suva. In 2012, it sent Clinton, still secretary of state, to the PIF, a first in the history of the organisation. Arguably, these actions were done in response to China's increasing presence in the 
Pacific. The rising power of China in the region was clearly the context for Clinton's 2009 comments and subsequent rhetoric associated with president Obama's Asia-Pacific pivot (Clinton 2011; Eckert 2011).

China could pose a strategic challenge and security risk to New Zealand's and its allies' domination of the Pacific. Despite President Trump undoing many of Obama's international commitments, including the Pacific pivot, the Trans-Pacific Partnership Agreement and the Paris Agreement on climate change, not much appears to have changed in the US's view of the Pacific. Vice President Pence's pre-APEC comments warning China about seeking undue influence, clearly referencing the Pacific, shows that the US continues to take the region seriously. In 2019, when Solomon Islands renounced its diplomatic recognition of Taipei in favour of Beijing, Pence cancelled a scheduled meeting with Prime Minister Sogavare, which was to have taken place on the sidelines of a United Nations General Assembly meeting in New York. According to Rampton (2019), a senior US official claimed the cancellation was due to the switch. If true, it is quite ironic; the US recognises Beijing, not Taipei.

Nevertheless, it shows the US's concern with China's increasing influence in the region.

However, perhaps more important are the broader implications of China's rising influence in the region. The Ministry of Defence's Strategic Defence Policy Statement 2018 identifies three key threats to the IRBO: spheres of influence, challenges to open societies and complex disruptors. China is important in relation to the first. Although New Zealand recognises that 'China is deeply integrated into the rules-based order', it believes China has 'not consistently adopted the governance and rules championed by the order's traditional leaders' (New Zealand Government 2018). In particular, China's positions on human rights and freedom of information are different from New Zealand's. Further, China does not follow the same 'model of development' as the West, preferring 'a liberalising economy absent liberal democracy' (ibid.). In terms of military power, New Zealand is concerned with the expansion of China's military presence in the Asian region, at times in contravention of conventional practices regarding sovereignty. While none of these issues are prominent in the Pacific, there is the odd sign that something of a similar nature might emerge. 
From a New Zealand perspective, Western allies need to retain control of security issues in the Pacific, and a Chinese military presence, should it eventuate, would threaten that control. This priority is somewhat evident in the Reset and related policies. In his Lowy Institute speech, Peters stated that national security was one of three reasons the Pacific was important for New Zealand. Though he did not mention China's rising influence, he did warn of great power ambitions in the region. In noting that the US was 'grappling' with the same realities as New Zealand, it is obvious he was not referring to the US itself. That leaves China. Notably, Peters urged Australia, the European Union and the US 'to better pool our energies and resources to maintain our relative influence' in the Pacific (Peters 2018a). Before attending a regional forum that included a meeting with US Secretary of State Mike Pompeo, Peters spoke of the need for those in the Western camp to address 'the new ball game' in the Pacific (Radio New Zealand 2018b). He did not clarify what the new ball game was. However, given his statements at the Lowy Institute and the 'spheres of influence' discussion in the Defence Statement, it is arguable that China is the focus. In November 2018, Peters announced the Pacific Enabling Fund as part of the Reset and stated that 'the coalition government is committed to rebuilding New Zealand's standing in the Pacific' and that the fund would allow engagement with Pacific partners on a range of activities that sit outside New Zealand's formal aid funding arrangements, including military cooperation activities (Peters 2018b). Steff (2018) notes:

Ultimately, balancing China in the South Pacific will require greater coordination with Australia-still the Pacific's largest donor-and reading out to other states. Japan, South Korea and the United States share concerns about China chipping away at their relative influence.

After decades of relative neglect, New Zealand recognises the need to reset its policies and reassert it and its allies influence in the region, with a focus on defence and security issues.

\section{Conclusion}

Whatever China's activities in the Pacific, whether building dual-purpose infrastructure or enticing countries into debt traps, it is clear that New Zealand has adopted the view that they warrant a considerable shift in its 
foreign policy approach, and this is manifest in the Reset. To be sure, this view is not explicit in New Zealand's statements concerning the Reset, and the New Zealand Government fervently denies that it is intended to counter China. Nevertheless, an analysis of related rhetoric and policy documents by the New Zealand Government indicate that the anxieties behind the Reset could not have been caused by any other actor in the region except China.

This view or representation of China must be understood in context. It comes after decades of neglect and a neo-colonial approach to the region, the result of a miscalculation on the part of New Zealand and its allies; they assumed the Pacific was under their control. Pacific loyalty was probably taken for granted. After decades of using aid as a political tool to leverage New Zealand's interests vis-à-vis those of the Pacific Island countries, the latter discovered a new source of power. With the rise in the number of external actors in the Pacific, particularly China, New Zealand's pride of place in the region, which it had developed through various security arrangements, is vulnerable. Regional geopolitics is changing, and China's growing presence is the key contributing factor. Compounding New Zealand's anxieties is the apparent vulnerability of Pacific Island countries to Chinese aid, giving rise to the debt-trap narrative. In the context of New Zealand's, and its allies', history in the region, China's presence has caused consternation to the extent that a policy like the Reset is warranted.

\section{References}

Bryant-Tokalau, J. and I. Frazer 2006. Redefining the Pacific? Regionalism Past, Present and Future. Farnham: Ashgate Publishing, Ltd.

Clinton, H. 2011. America's Pacific Century. Foreign Policy, 11 October. www. foreignpolicy.com/2011/10/11/americas-pacific-century/

Crocombe, R. 2007. Asia in the Pacific Islands: Replacing the West. Suva: IPS Publications, University of the South Pacific.

Davies, A. 2009. US Not 'Ceding the Pacific': Clinton. The Sydney Morning Herald, 20 May. www.smh.com.au/world/us-not-ceding-the-pacific-clinton20090520-bei8.html

Diamond, L. and O. Schell 2018. China's Influence and American Interests: Promoting Constructive Vigilance. Stanford: Hoover Institution Press. 
Doherty, B. 2016. Secret Russian Arms Donation to Fiji Raises Concerns of Bid for Pacific Influence. The Guardian, 22 January. www.theguardian.com/ world/2016/jan/22/secretive-shipment-of-arms-donated-by-russia-to-fijiraises-concerns

Eckert, P. 2011. Clinton Declares 'America’s Pacific Century'. Reuters, 12 November. www.reuters.com/article/us-apec-usa-clinton-f/clinton-declares-americaspacific-century-idUSTRE7AA2S120111111

Fox, R. and M. Dornan 2018. China in the Pacific: Is China Engaged in 'DebtTrap Diplomacy'? Devpolicy Blog, 8 November. www.devpolicy.org/is-chinaengaged-in-debt-trap-diplomacy-20181108/

Fry, G. and S. Tarte 2015. The 'New Pacific Diplomacy': An Introduction. In G. Fry and S.Tarte. The New Pacific Diplomacy. Canberra: ANU Press. doi.org/10.22459/NPD.12.2015.01

Garrick, J. 2018. Soft Power Goes Hard: China’s Economic Interest in the Pacific Comes with Strings Attached. The Conversation, 17 October. theconversation. $\mathrm{com} /$ soft-power-goes-hard-chinas-economic-interest-in-the-pacific-comeswith-strings-attached-103765

Global Construction Review 2017. China to Build Papua New Guinea's First National Road System. 24 November. globalconstructionreview.com/news/ china-build-papua-new-guineas-first-national-road-/

Henderson, J. 1999. New Zealand and Oceania. In B. Brown (ed.), New Zealand in World Affairs 1972-1990. Auckland: New Zealand Institute of International Affairs.

Henderson, J. and B. Reilly 2003. Dragon in Paradise: China's Rising Star in Oceania. The National Interest Summer(72):94-104.

Hensley, G. 2013. Friendly Fire: Nuclear Politics and the Collapse of ANZUS, 1984-1987. Auckland: Auckland University Press.

Kehoe, J. 2018. US Report: China 'Debt Trap' on Australia’s Doorstep. Financial Review, 13 May. www.afr.com/news/politics/world/us-secret-report-chinadebt-trap-on-australias-doorstep-20180513-h0zzwd

Klan, A. 2018. Pacific Nations Drowning in Chinese Debt. The Australian, 29 January. www.theaustralian.com.au/nation/politics/pacific-nations-drowningin-chinese-debt/news-story/082de1ecc957c9c4380bb9cb8555fa95

Knaus, C. 2017. Australian Air Force Put on Alert after Russian Long-Range Bombers Headed South. The Guardian, 30 December. www.theguardian.com/ world/2017/dec/30/australian-military-alert-russia-bombers-indonesia-exercises 
Lintner, B. 2018. China Advances, West Frets in South Pacific. Asia Times, 25 April. www.asiatimes.com/2018/04/china-advances-west-frets-in-south-pacific/

Mapp, W. 2014. The New Zealand Paradox: Adjusting to the Change in Balance of Power in the Asia-Pacific over the Next 20 Years. Lanham: Rowman and Littlefield.

McIntyre, W.D. 1995. Background to the ANZUS Pact: Policy-Making, Strategy and Diplomacy, 1945-1955. Christchurch: St Martin's Press, Canterbury University Press.

McKinnon, D. 1998. Australia-New Zealand Defence Ministerial Talks. New Zealand Government, 27 March. www.beehive.govt.nz/feature/australianew-zealand-defence-ministerial-talks

Muraviev, A. 2018. Russia Is a Rising Military Power in the Asia-Pacific, and Australia Needs to Take It Seriously. The Conversation, 31 October. www. abc.net.au/news/2018-10-31/russia-is-a-rising-military-power-in-the-asiapacific/ 10447190

New Zealand Government 2018. Strategic Defence Policy Statement. Wellington: Ministry of Defence.

New Zealand Government 2019. Advancing Pacific Partnerships 2019. 29 October. Wellington: Ministry of Defence. www.defence.govt.nz/assets/publication/file/ 5f6dd307e7/Advancing-Pacific-Partnerships-2019.pdf

Novak, C. 2018. New Zealand's China Reset? The Strategist, 20 December. Australian Strategic Policy Institute. www.aspistrategist.org.au/new-zealandschina-reset/

O'Keefe, M. 2018. Why China's 'Debt-Book Diplomacy' in the Pacific Shouldn't Ring Alarm Bells Just Yet. The Conversation, 17 May. theconversation.com/ why-chinas-debt-book-diplomacy-in-the-pacific-shouldnt-ring-alarm-bellsjust-yet-96709

Parker, S. and G. Chefitz 2018. Debtbook Diplomacy China's Strategic Leveraging of its Newfound Economic Influence and the Consequences for US Foreign Policy. Cambridge: Belfer Center for Science and International Affairs.

Peters, W. 2018a. 'Shifting the Dial': Eyes Wide Open, Pacific Reset. Speech at the Lowy Institute, Sydney, 1 March. www.lowyinstitute.org/publications/ winston-peters-new-zealand-pacific

Peters, W. 2018b. Pacific Reset Picks Up Pace. News release, 8 November. www. beehive.govt.nz/release/pacific-reset-picks-pace 
Power, J. 2018. China: The Real Reason Australia’s Pumping Cash into the Pacific? South China Morning Post, 28 July. www.scmp.com/week-asia/geopolitics/ article/2157169/china-real-reason-australias-pumping-cash-pacific

Powles, A. and M. Powles 2017. New Zealand's Pacific Policies-Time for a Reset? New Zealand International Review 42(2):16-21.

Radio New Zealand 2018a. Academic Questions Significance of UK's Pacific Ramp Up. 20 April. www.radionz.co.nz/international/pacific-news/355609/ academic-questions-significance-of-uk-s-pacific-ramp-up

Radio New Zealand 2018b. Peters Says World Needs to Address 'New Ball Game' in the Pacific. 31 July. www.radionz.co.nz/international/pacific-news/363062/ peters-says-world-needs-to-address-new-ball-game-in-the-pacific

Radio New Zealand 2018c. US Calls Out China on 'Debt-Trap' Diplomacy. 5 October. www.radionz.co.nz/international/pacific-news/367997/us-callsout-china-on-debt-trap-diplomacy

Radio New Zealand 2018d. Japan and NZ Join Forces to Help Pacific. 15 October. www.radionz.co.nz/international/pacific-news/368699/japanand-nz-join-forces-to-help-pacific

Radio New Zealand 2018e. Tonga and Vanuatu Join China's Belt and Road. 20 November. www.radionz.co.nz/international/pacific-news/376372/tongaand-vanuatu-join-china-s-belt-and-road

Radio New Zealand 2018f. Government Has Its 'Eyes Wide Open' on China: Winston Peters. 4 December. www.radionz.co.nz/news/political/377436/ government-has-its-eyes-wide-open-on-china-winston-peters

Radio New Zealand 2018g. NZ Ups Its Diplomatic Presence in Pacific. 4 December. www.radionz.co.nz/international/pacific-news/377458/nz-upsits-diplomatic-presence-in-pacific

Rampton, R. 2019. Exclusive: Pence Rebuffs Solomon Islands PM After Nation Cuts Ties with Taiwan. Reuters, 18 September. www.reuters.com/article/ustaiwan-diplomacy-pence-exclusive/exclusive-pence-rebuffs-solomon-islandspm-after-nation-cuts-ties-with-taiwan-idUSKBN1W22WK

Reuters 2018. NZ Ramps up Diplomatic Presence in Pacific Where China Influence Rising. 4 December. www.reuters.com/article/us-newzealand-pacific/ nz-ramps-up-diplomatic-presence-in-pacific-where-china-influence-risingidUSKBN1O3094

Riordan, P. 2018. Russian Warship Due to Dock in Port Moresby. The Australian, 14 May. www.theaustralian.com.au/nation/defence/russian-warship-due-todock-in-port-moresby/news-story/dfd439d2e840f23139558e61181f5dd4 
Robertson, P.E. and A. Sin 2017. Measuring Hard Power: China's Economic Growth and Military Capacity. Defence and Peace Economics 28(1):91-111. doi.org/10.1080/10242694.2015.1033895

Seidel, J. 2018. China Almost Has Australia Surrounded. But Its Debt-Trap Diplomacy Has Been Exposed. news.com.au, 25 September. www.news.com. $\mathrm{au} /$ world/pacific/china-almost-has-australia-surrounded-but-its-debttrapdiplomacy-has-been-exposed/news-story/3f8d390e8c8e3b5158214836ee412aee

Steff, R. 2018. New Zealand's Pacific Reset: Strategic Anxieties about Rising China. The Conversation, 1 June. www.theconversation.com/new-zealandspacific-reset-strategic-anxieties-about-rising-china-97174

Tarte, S. 1989. Regionalism and Globalism in the South Pacific. Development and Change 20:181-201.

The Economic Times 2018. China Slams Mike Pence; Says No Country in Debt Trap Because of BRI. 18 November. economictimes.indiatimes.com/news/ international/world-news/china-slams-mike-pence-says-no-country-in-debttrap-because-of-bri/articleshow/66679080.cms

Uhlmann, C. 2018. PM Warns China Not to Consider Building Naval Base in the South Pacific. 9News, 10 April. www.9news.com.au/world/australiandefence-force-china-will-upset-power-balance-in-south-pacific-vanuatunaval-base/34d9bc89-fa7a-49c9-9985-34c17163d68c

Vandenbosch, A. and M.B. Vandenbosch 1967. Australia Faces Southeast Asia: The Emergence of a Foreign Policy. Lexington: University of Kentucky Press.

Walsh, M. 2018. Pacific Leaders More Questioning of Chinese Influence. Radio New Zealand, 24 November. www.radionz.co.nz/news/world/376732/pacificleaders-more-questioning-of-chinese-influence

Walters, L. 2018a. PM Opposes Pacific Militarisation As China Eyes Vanuatu Military Base. Stuff, 10 April. www.stuff.co.nz/national/politics/102971730/ pm-opposes-pacific-militarisation-as-china-eyes-vanuatu-military-base

Walters, L. 2018b. New \$180m Fund to Help Counter NZ's 'Decreasing Influence' in Pacific. Stuff, 3 July. www.stuff.co.nz/national/politics/105183983/new$180 \mathrm{~m}$-fund-to-help-counter-nzs-decreasing-influence-in-pacific

Wroe, D. 2018. China Eyes Vanuatu Military Base in Plan with Global Ramifications. The Sydney Morning Herald, 9 April. www.smh.com.au/politics/ federal/china-eyes-vanuatu-military-base-in-plan-with-global-ramifications20180409-p4z8j9.html

Wu, W. 2018. Beyond the 'Chinese Debt Trap'. The Interpreter, 30 May. Lowy Institute. www.lowyinstitute.org/the-interpreter/beyond-chinese-debt-trap 
This text is taken from The China Alternative: Changing Regional Order in the Pacific Islands, edited by Graeme Smith and Terence Wesley-Smith, published 2021 by ANU Press, The Australian National University, Canberra, Australia.

doi.org/10.22459/CA.2021.04 